\title{
Ethics and Information Technology (ETIT)
}

DOI: http://doi.org/10.26480/etit.02.2020.173.178

ISBN: 978-1-948012-17-1

\section{REVIEW ARTICLE}

\section{A NEW AND SUSTAINABLE PKL ELECTRICITY}

\author{
K.A. Khan ${ }^{a}$, Shahinul Islamb ${ }^{b}$ M. A. Saimec, S. R. Raseld, Sazzad Hossain ${ }^{\mathrm{e}}$ \\ aDepartment of Physics, Jagannath University, Dhaka-1100, Bangladesh \\ ${ }^{b}$ Department of Physics, Uttara University, Dhaka, Bangladesh \\ ${ }^{c}$ Chief Instructor (Tech) Computer, Dinajpur Polytechnique Institute. \\ ${ }^{d}$ Local Government Engineering Department (LGED), Fulbaria, Mymensing, Bangladesh \\ eShantinagar Plaza (1st floor), 124/2, New Kakrail Road, Dhaka-1000 \\ *Corresponding Author E-mail: mptltd.bd@gmail.com; kakhan01@yahoo.com
}

This is an open access article distributed under the Creative Commons Attribution License CC BY 4.0, which permits unrestricted use, distribution, and reproduction in any medium, provided the original work is properly cited.

\section{ARTICLE DETAILS}

\section{Article History:}

Received 18 February 2021

Accepted 11 March 2021

Available online 15 March 2021

\begin{abstract}
A new method of electricity generation based on Pathor Kuchi Leaf (Genus: Kalanchoe, Section: Bryophyllum) has been developed at the Department of Physics, Jagannath University, Dhaka- 1100, Bangladesh. This electricity generation method has several advantages for smart grid over the conventional electricity production. This sustainable method is likely to generate the employment at particularly in the rural areas of where grid electricity is absent. This research work reports an invention made on Pathor Kuchi Leaf (PKL) electric power plant to enhance the PKL electricity production. The efficiency of the PKl electricity production device, Short Circuit Current ( Isc ), Open circuit Voltage ( Voc ), Temperature effect of the PKL malt, $\mathrm{p}^{\mathrm{H}}$ of the PKL malt, Titratable acidity of the PKL malt, Generation of PKL electricity, Storage system of the PKL electricity, Particular utilization of PKL electricity, I-V characteristics of the PKL, Classification of PKL, Longevity of PKL malt for PKL electricity generation, Preparation of PKL electric unit cell, module, panel, arrays and the constituent elements of the PKL, Voltage regulation, Internal resistance of the cell and efficiency of the cell have been studied. The chemical reactions of the PKL electrochemical cell have also been studied. In experimental study, it is shown that the maximum efficiency of the PKL electricity production device is $\approx 34 \%$, the pH of the PKL malt is $\approx 4.6$ (without water), $\mathrm{pH}$ of the PKL malt is $\approx 4.8$ (with $10 \%$ solution), the titratable acidity of the PKL malt is $\approx 0.88 \%$. Most of the results have been tabulated and graphically discussed.
\end{abstract}

\section{KEYWORDS}

PKL Electricity, DC appliances, I-V characteristics, Power variation, $\mathrm{pH}$ variation, Cultivation.

\section{INTRODUCTION}

Electricity has a great impaction development of a society. In Bangladesh only 30-35 per cent of total population can use electricity from national grid. Energy consumption per capita is extremely low compared to neibouring countries (Hamid, 2013). It is half of Nepal and one fourth of India. In Bangladesh average demand of electricity is 5,200 MW, but average generation is 3,300 MW. Low consumption of electricity is affecting the entire development of the country (Hamid et al., 2016). Due to power shortage education, business, health, services, agriculture and other productive works have been constantly hampered. It can not expect that in near future it will be possible to extend the grid system up to the remote village in the country. The total power generation in Bangladesh mostly depends of fossil fuels (Pal and Chaudhuri, 1991; Supratman et al., 2000; Ojewole, 2005; Asiedu-Gyekye et al., 2012; Ojewole, 2002; Okwu and Josiah, 2006; Cao et al., 2005; Yamagishi et al., 1989; Marriage and Wilson, 1971). Though use of fossil fuels enhances green house emission but for electricity generation natural gas is the major energy source $(90 \%)$ and Bangladesh will not be able to arrange electricity from fusion reactors in near future (Osujih, 1993; Saad et al., 2006; Larrey et al., 1994; Jagessar and Allen, 2012; Tietz et al., 1986; Weatherbum, 1967; Ochei and Kolhatker, 2002). So it is required to search alternative sources of electric power. Electricity can play a vital role in poverty alleviation in this country. Government programmes and messages play strong role in development of society in under developed countries like Bangladesh. To keep this in mind pathor kuchi leaf have been used to produce electricity. The electricity generation by Pathor Kuchi Leaf (PKL) was prototype (Amelar et al., 1973; Ozolua et al., 2010; Michael et al., 2007; Biswas et al., 2011; Obianime et al., 2010; Aprioku and Obianime, 2014; Guyton, 2006; Zhang et al., 2010). It has been observed that the longsivity of the voltage generation from Pathor Kuchi Leaf (PKL) very satisfactory. So we can cultivate the Pathor Kuchi Leaf (PKL) in our field and can generate more electricity by setting -up a power plant by using Pathor Kuchi Leaf (PKL) can show a guide line to the nation of Bangladesh. It is very new one research project in Bangladesh.

\section{Methodology}

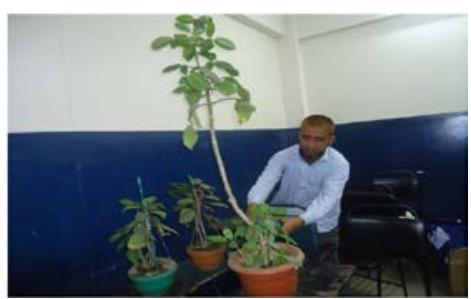

Figure 1: A researcher is cultivating PKL living tree
Website:
DOI: 10.26480/etit.02.2020.173.178 
Figure 1 shows the PKL tree for Electricity generation. The leaf was collected from the leaf and then it was blended manually by a machine (Figure 2). The PKL tree has been cultivated in a soil pot.

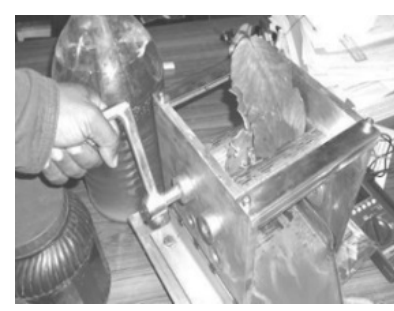

(a)

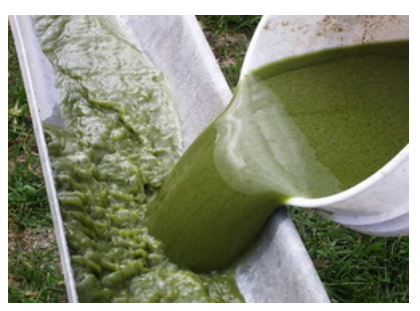

(b)
Figure 2: (a) Extract machine, (b) Filtered juice

Figure 2 Preparation of PKL extract by a manual machine in Figure 2 (a) and filtration in Figure 2 (b) Figure 2 shows a prototype manual machine for Preparation of PKL extract. It has been prepared manually. After preparation of pkl extract it has been filtered and then it was used for electricity preparation.

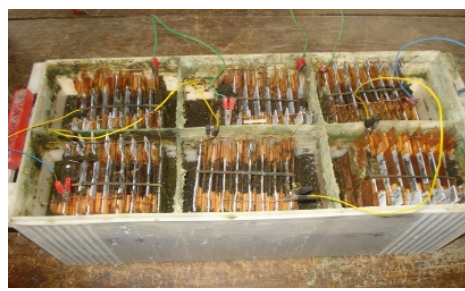

(a)

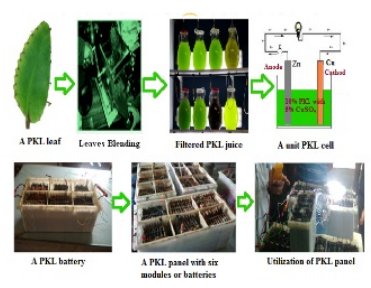

(b)
Figure 3: (a) Design and fabrication of PKL module; (b) Complete cycle of PKL electricity generation system

Figure 3 An experimental set up for a PKL module in both series and parallel connection inside the box (without load) in Figure 3 (a) and complete cycle of PKL electricity generation system with a load in Figure 3 (b). It is shown in Fig.3, the PKL modules is different for different electrodes. The electrodes were made by zinc and copper materials. The electrolyte was prepared by PKL extract with different concentration. The connecting material was made by copper wire. The box was made by plastic materials. Each box has 6 compartments. The electrodes were placed in each boxes are in parallel connection for making PKL electrochemical cell. The connections among the PKL electrochemical cells are in series combinations. The electrolyte was put in each compartment and then electricity was generated. It is mentioned that the produced electricity was DC. To make it AC it is needed an inverter which can convert electricity from DC to AC.

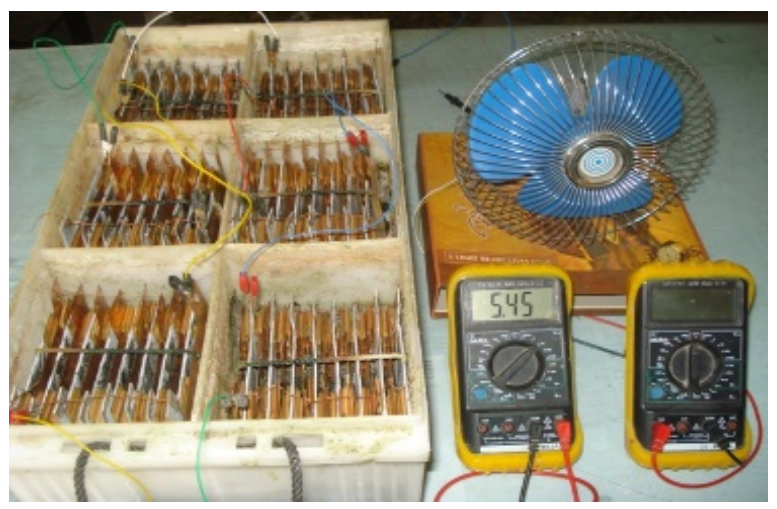

Figure 4: An experimental set up PKL electric module with DC load (Table Fan)

Figure 4 shows the practical utilization of PKL electricity with a DC fan. It can be used for any kind of DC appliances a load. The calibrated multimeters were used to measure current, voltage and power accurately.

\section{RESUlts ANd DiscuSSiON}

For different loads (Television and Radio), the data has been collected and also tabulated for different date of the months which has been tabulated in different Table 1 to Table 1 to Table 8.

Date: $04.11 .09-1^{\text {st }}$ day

\begin{tabular}{|c|c|c|c|c|c|c|c|c|c|}
\hline $\begin{array}{l}\text { Localtime } \\
\text { (min) }\end{array}$ & $\begin{array}{l}\text { Time } \\
\text { duration(min) }\end{array}$ & $\begin{array}{l}\text { Open } \\
\text { circuit } \\
\text { voltage } \\
\mathrm{V}_{\text {oc }}(\mathrm{V})\end{array}$ & $\begin{array}{l}\text { Short } \\
\text { circuit } \\
\text { current, } \\
\mathrm{I}_{\text {sc }}(\mathrm{A})\end{array}$ & $\begin{array}{l}\text { Load } \\
\text { Voltage } \\
\mathrm{V}_{\mathrm{L}}(\mathrm{V})\end{array}$ & $\begin{array}{l}\text { Load } \\
\text { Current, } \\
\mathrm{I}_{\mathrm{L}}(\mathrm{A})\end{array}$ & $\begin{array}{l}\text { Load } \\
\text { Power,PL(W) }\end{array}$ & $\begin{array}{l}\text { Ambient } \\
\text { Temp, } \mathrm{T}_{\mathrm{a}} \\
\left({ }^{\circ} \mathrm{C}\right)\end{array}$ & $\begin{array}{l}\text { Juice } \\
\text { Temp } \\
\left({ }^{\circ} \mathrm{C}\right)\end{array}$ & $\begin{array}{l}\text { MaximumPower, } \mathrm{P}_{\max }=\left(\mathrm{V}_{\mathrm{oc}}\right)\left(\mathrm{I}_{\mathrm{sc}}\right) \\
\mathrm{W}\end{array}$ \\
\hline $12.00 \mathrm{pm}$ & 00 & & & 4.06 & 0.45 & 1.83 & 28 & 26 & 8.92 \\
\hline $12.05 \mathrm{pm}$ & 05 & \multirow{17}{*}{6.67} & & 4.06 & 0.45 & 1.83 & 28 & 26 & \\
\hline $12.10 \mathrm{pm}$ & 10 & & & 3.91 & 0.44 & 1.72 & 27 & 26 & \\
\hline $12.15 \mathrm{pm}$ & 15 & & \multirow{15}{*}{1.35} & 3.73 & 0.43 & 1.60 & 28 & 25 & \\
\hline $12.20 \mathrm{pm}$ & 20 & & & 3.51 & 0.43 & 1.51 & 28 & 26 & \\
\hline $12.25 \mathrm{pm}$ & 25 & & & 3.31 & 0.42 & 1.39 & 27 & 26 & \\
\hline $12.30 \mathrm{pm}$ & 30 & & & 2.99 & 0.41 & 1.23 & 27 & 26 & \\
\hline $12.35 \mathrm{pm}$ & 35 & & & 2.77 & 0.40 & 1.11 & 28 & 26 & \\
\hline $12.40 \mathrm{pm}$ & 40 & & & 2.65 & 0.39 & 1.03 & 28 & 26 & \\
\hline $12.45 \mathrm{pm}$ & 45 & & & 2.51 & 0.37 & 0.91 & 27 & 25 & \\
\hline $12.50 \mathrm{pm}$ & 50 & & & 2.38 & 0.36 & 0.86 & 28 & 25 & \\
\hline $12.55 \mathrm{pm}$ & 55 & & & 2.22 & 0.34 & 0.76 & 28 & 25 & \\
\hline $1.00 \mathrm{pm}$ & 60 & & & 2.09 & 0.33 & 0.69 & 28 & 26 & \\
\hline $1.05 \mathrm{pm}$ & 65 & & & 2.08 & 0.33 & 0.69 & 28 & 26 & \\
\hline $1.10 \mathrm{pm}$ & 70 & & & 1.96 & 0.32 & 0.68 & 28 & 26 & \\
\hline $1.15 \mathrm{pm}$ & 75 & & & 1.89 & 0.30 & 0.57 & 27 & 25 & \\
\hline $1.20 \mathrm{pm}$ & 80 & & & 1.69 & 0.29 & 0.49 & 27 & 25 & \\
\hline $1.25 \mathrm{pm}$ & 85 & & & 1.60 & 0.28 & 0.45 & 27 & 25 & \\
\hline
\end{tabular}




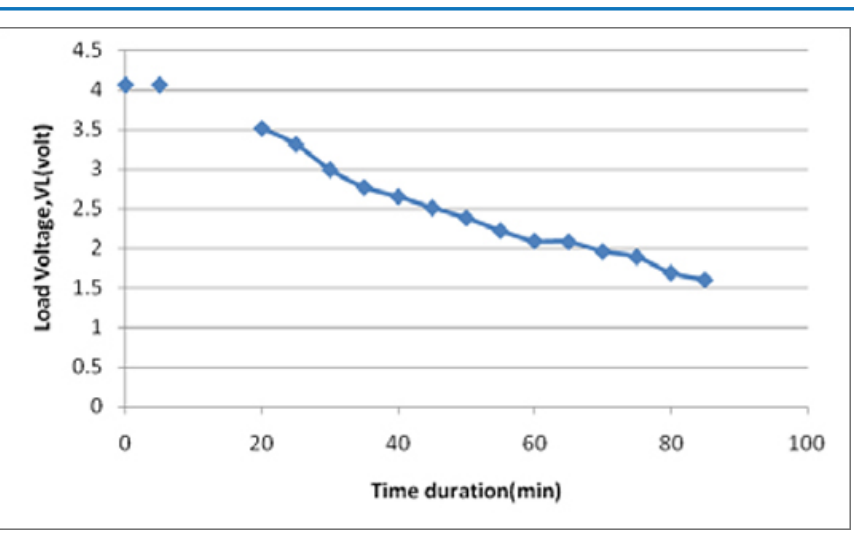

Figure 5: Variation of load voltage with the variation of time duration

Figure 5 shows the Variation of load voltage with the variation of time duration for 80 minutes on $1^{\text {st }}$ day with 12 volt DC fan. It is shown that the load voltage variation from 4.06 volt to 1.6 volt. The change of load voltage variation was $2.46 \mathrm{~V}$.

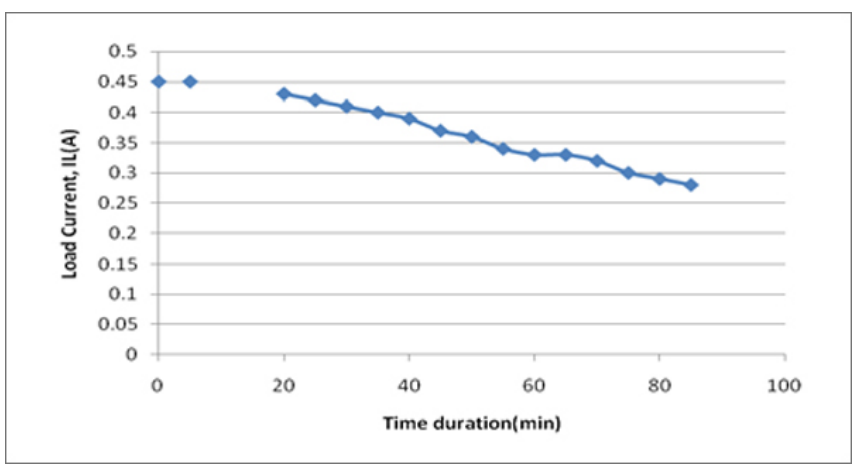

Figure 6. Variation of load current with the variation of time duration

Figure 6 shows the Variation of load corrent with the variation of time duration for 80 minutes on $1^{\text {st }}$ day with 12 volt $\mathrm{DC}$ fan. It is shown that the voltage variation from $0.45 \mathrm{~A}$ to $0.28 \mathrm{~A}$. The change of load current variation was $0.17 \mathrm{~A}$

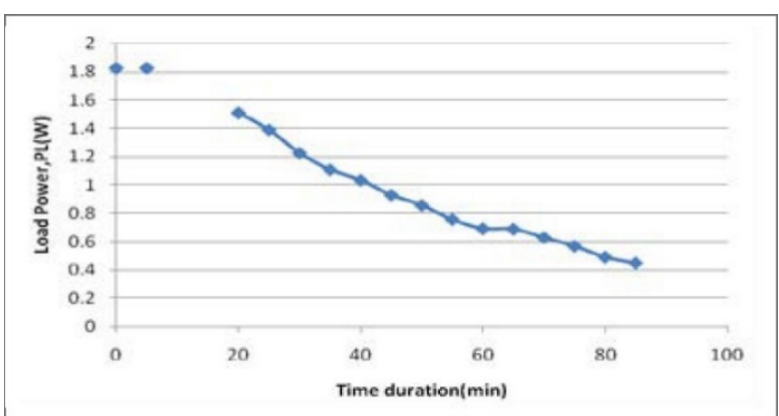

Figure 7: Variation of load power with the variation of time duration

Figure 7 shows the Variation of load power with the variation of time duration for 80 minutes on $1^{\text {st }}$ day with 12 volt $D C$ fan. It is shown that the load power variation from $1.83 \mathrm{~W}$ to $0.45 \mathrm{~W}$. The change of load power variation was $1.38 \mathrm{~W}$.

Date: $05.11 .09-2^{\text {nd }} d a y$

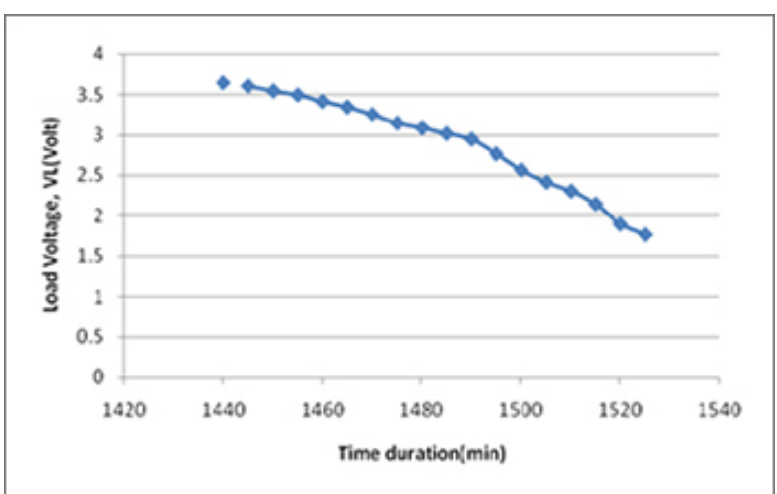

Figure 8: Variation of load voltage with the variation of time duration

Figure 8 shows the Variation of load power with the variation of time duration for 1225 minutes on $2^{\text {nd }}$ day with 12 volt DC fan. It is shown that the voltage variation from $3.65 \mathrm{~V}$ to $1.77 \mathrm{~V}$. The change of load voltage variation was $1.88 \mathrm{~V}$

\begin{tabular}{|c|c|c|c|c|c|c|c|c|c|}
\hline $\begin{array}{l}\text { LocalTime( } \\
\text { min) }\end{array}$ & $\begin{array}{l}\text { Time } \\
\text { duration( } \\
\text { min) }\end{array}$ & $\begin{array}{l}\text { OpenCircuitVoltag } \\
\text { e, } V_{o c}(V)\end{array}$ & $\begin{array}{l}\text { ShortCircuitCur } \\
\text { rent, }, I_{s c},(A)\end{array}$ & $\begin{array}{l}\text { Load } \\
\text { Voltage, } \mathrm{V} \\
\mathrm{L}(\mathrm{V})\end{array}$ & $\begin{array}{l}\text { Current,I } \\
\text { L(A) }\end{array}$ & $\begin{array}{l}\text { Power, } \mathrm{P}_{\mathrm{L}} \\
\text { (W) }\end{array}$ & $\begin{array}{l}\text { AmbientTem } \\
\text { p. }\left({ }^{\circ} \mathrm{C}\right)\end{array}$ & $\begin{array}{l}\text { Juice } \\
\text { Temp( } \\
\left.{ }^{\circ} \mathrm{C}\right)\end{array}$ & $\begin{array}{l}\text { MaximumPow } \\
\text { er(W) }\end{array}$ \\
\hline $12.00 \mathrm{pm}$ & 1440 & & \multirow{18}{*}{1.15} & 3.65 & 0.32 & 1.17 & 28 & 26 & 6.95 \\
\hline $12.05 \mathrm{pm}$ & 1445 & \multirow{17}{*}{6.04} & & 3.61 & 0.32 & 1.16 & 28 & 26 & \\
\hline $12.10 \mathrm{pm}$ & 1450 & & & 3.55 & 0.31 & 1.10 & 27 & 26 & \\
\hline $12.15 \mathrm{pm}$ & 1455 & & & 3.50 & 0.30 & 1.05 & 28 & 25 & \\
\hline $12.20 \mathrm{pm}$ & 1460 & & & 3.42 & 0.29 & 0.99 & 28 & 26 & \\
\hline $12.25 \mathrm{pm}$ & 1465 & & & 3.35 & 0.27 & 0.90 & 27 & 26 & \\
\hline $12.30 \mathrm{pm}$ & 1470 & & & 3.26 & 0.26 & 0.85 & 27 & 26 & \\
\hline $12.35 \mathrm{pm}$ & 1475 & & & 3.15 & 0.26 & 0.82 & 28 & 26 & \\
\hline $12.40 \mathrm{pm}$ & 1480 & & & 3.09 & 0.25 & 0.77 & 28 & 26 & \\
\hline $12.45 \mathrm{pm}$ & 1485 & & & 3.02 & 0.24 & 0.72 & 27 & 25 & \\
\hline $12.50 \mathrm{pm}$ & 1490 & & & 2.95 & 0.23 & 0.6785 & 28 & 25 & \\
\hline $12.55 \mathrm{pm}$ & 1495 & & & 2.77 & 0.22 & 0.61 & 28 & 25 & \\
\hline $1.00 \mathrm{pm}$ & 1500 & & & 2.57 & 0.22 & 0.57 & 28 & 26 & \\
\hline $1.05 \mathrm{pm}$ & 1505 & & & 2.42 & 0.21 & 0.51 & 28 & 26 & \\
\hline $1.10 \mathrm{pm}$ & 1510 & & & 2.31 & 0.20 & 0.46 & 28 & 26 & \\
\hline $1.15 \mathrm{pm}$ & 1515 & & & 2.15 & 0.19 & 0.41 & 27 & 25 & \\
\hline $1.20 \mathrm{pm}$ & 1520 & & & 1.90 & 0.17 & 0.32 & 27 & 25 & \\
\hline $1.25 \mathrm{pm}$ & 1525 & & & 1.77 & 0.15 & 0.27 & 27 & 25 & \\
\hline
\end{tabular}




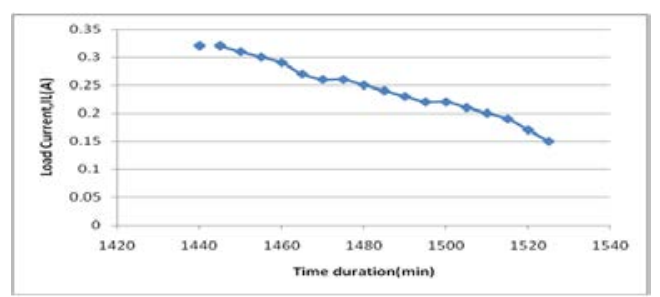

Figure 9: Variation of load current with the variation of time duration

Figure 9 shows the Variation of load current with the variation of time duration for 1225 minutes on $2^{\text {nd }}$ day with 12 volt DC fan. It is shown that the voltage variation from $0.32 \mathrm{~A}$ to $0.15 \mathrm{~A}$. The change of load current variation was $0.17 \mathrm{~A}$.

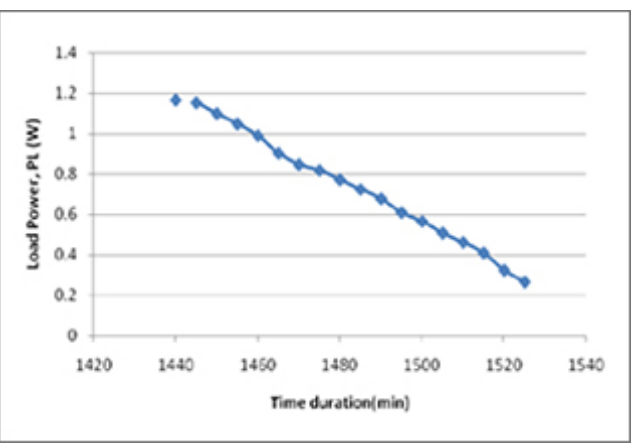

Figure 10: Variation of load power with the variation of time duration

Figure 10 shows the Variation of load power with the variation of time duration for 1225 minutes on $2^{\text {nd }}$ day with 12 volt DC fan. It is shown that the load power variation from $1.17 \mathrm{~W}$ to $0.27 \mathrm{~W}$. The change of load power variation was $0.90 \mathrm{~V}$.

Date: $06.11 .09-3^{\text {rd }}$ day

\begin{tabular}{|c|c|c|}
\hline Local time (min) & Time duration (min) & $\begin{array}{l}\text { Open circuit Voltage, Voc } \\
\text { (V) }\end{array}$ \\
\hline $11.30 \mathrm{am}$ & 2840 & 6.65 \\
\hline $11.35 \mathrm{am}$ & 2845 & 6.63 \\
\hline $11.40 \mathrm{am}$ & 2850 & 6.63 \\
\hline $11.45 \mathrm{am}$ & 2855 & 6.62 \\
\hline $11.50 \mathrm{am}$ & 2860 & 6.61 \\
\hline $11.55 \mathrm{am}$ & 2865 & 6.61 \\
\hline $12.00 \mathrm{pm}$ & 2870 & 6.60 \\
\hline $12.05 \mathrm{pm}$ & 2875 & 6.61 \\
\hline $12.10 \mathrm{pm}$ & 2880 & 6.60 \\
\hline $12.15 \mathrm{pm}$ & 2885 & 6.60 \\
\hline
\end{tabular}

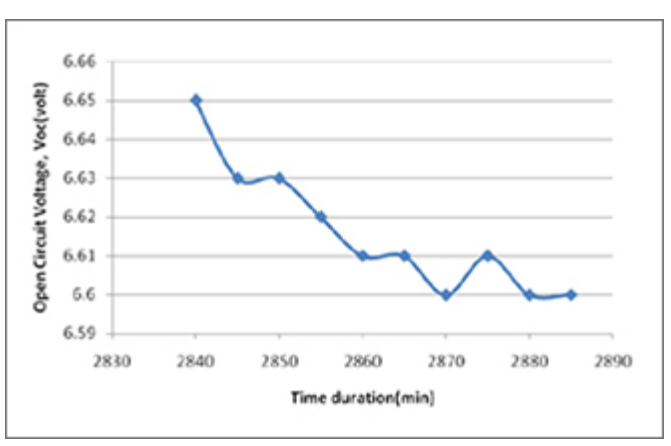

Figure 11: Variation of load opencircuit voltage with the variation of time duration

Figure 11 shows the variation of open circuit voltage with the variation of time duration for 2885 minutes on $3^{\text {rd }}$ day without load. It is shown that the open circuit voltage variation from $6.65 \mathrm{~V}$ to $6.60 \mathrm{~V}$. The change of opencircuit voltage was $0.05 \mathrm{~V}$.

Date: 06.11.09-3 ${ }^{\text {rd }}$ day

\begin{tabular}{|c|c|c|}
\hline \multicolumn{3}{|c|}{$\begin{array}{l}\text { Table 4: Variation of current with the variation of Local time for } \\
\text { without load. }\end{array}$} \\
\hline $\begin{array}{l}\text { Local time } \\
\quad \text { (min) }\end{array}$ & $\begin{array}{l}\text { Time } \\
\text { duration(min) }\end{array}$ & Short Circuit Current, Isc (A) \\
\hline $11.00 \mathrm{am}$ & 2810 & 1.35 \\
\hline $11.05 \mathrm{am}$ & 2815 & 1.34 \\
\hline $11.10 \mathrm{am}$ & 2820 & 1.34 \\
\hline $11.15 \mathrm{am}$ & 2825 & 1.35 \\
\hline $11.20 \mathrm{am}$ & 2830 & 1.32 \\
\hline $11.25 \mathrm{am}$ & 2835 & 1.31 \\
\hline $11.30 \mathrm{am}$ & 2840 & 1.34 \\
\hline $11.35 \mathrm{am}$ & 2845 & 1.33 \\
\hline $11.40 \mathrm{am}$ & 2850 & 1.33 \\
\hline $11.45 \mathrm{am}$ & 2855 & 1.32 \\
\hline
\end{tabular}

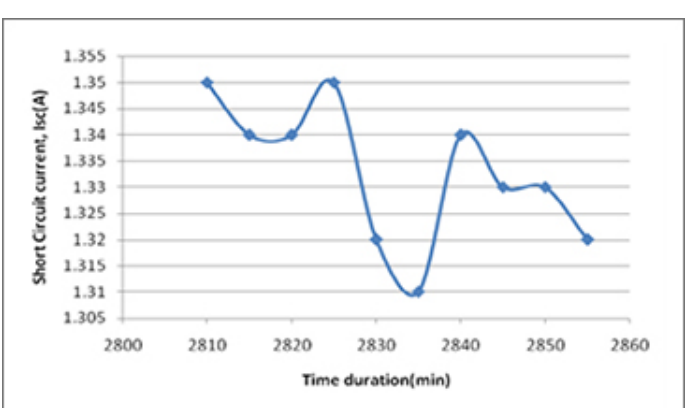

Figure 12: Variation of load short circuit current with the variation of time duration

Figure 12 shows the variation of short circuit current with the variation of time duration for 2885 minutes on $3^{\text {rd }}$ day without load. It is shown that the open circuit voltage variation from $1.35 \mathrm{~A}$ to $1.32 \mathrm{~A}$. The change of short circuit current was $0.053 \mathrm{~A}$.

Date: 07.11.09 - $4^{\text {th }}$ day

\begin{tabular}{|c|c|c|}
\hline \multicolumn{3}{|c|}{ Table 5: Variation of voltage with the variation of Local time with } \\
load (Fan). \\
\hline $\begin{array}{c}\text { Local time } \\
(\mathrm{min})\end{array}$ & Time duration(min) & Voltage (with load) (V) \\
\hline $10.00 \mathrm{am}$ & 4190 & 4.30 \\
\hline $10.05 \mathrm{am}$ & 4195 & 4.15 \\
\hline $10.10 \mathrm{am}$ & 4200 & 4.07 \\
\hline $10.15 \mathrm{am}$ & 4205 & 4.02 \\
\hline $10.20 \mathrm{am}$ & 4210 & 3.89 \\
\hline $10.25 \mathrm{am}$ & 4215 & 3.75 \\
\hline $10.30 \mathrm{am}$ & 4220 & 3.68 \\
\hline $10.35 \mathrm{am}$ & 4225 & 3.62 \\
\hline $10.40 \mathrm{am}$ & 4230 & 3.55 \\
\hline $10.45 \mathrm{am}$ & 4235 & 3.50 \\
\hline
\end{tabular}

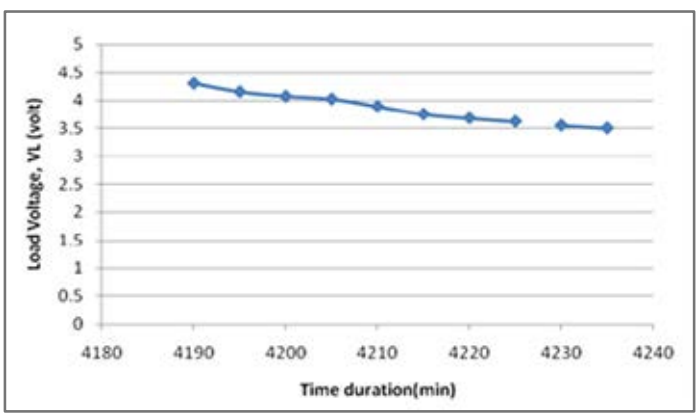

Figure 13. Variation of load opencircuit voltage with the variation of time duration 
Figure 13 shows the variation of load voltage with the variation of time duration for 4235 minutes on $4^{\text {th }}$ day without load. It is shown that the open circuit voltage variation from $1.35 \mathrm{~A}$ to $1.32 \mathrm{~A}$. The change of short circuit current was $0.03 \mathrm{~A}$.

Date: $08.11 .09-5^{\text {th }}$ day

\begin{tabular}{|c|c|c|}
\hline \multicolumn{3}{|c|}{ Table 6: Variation of current with the variation of Local time with } \\
load (Fan).
\end{tabular}

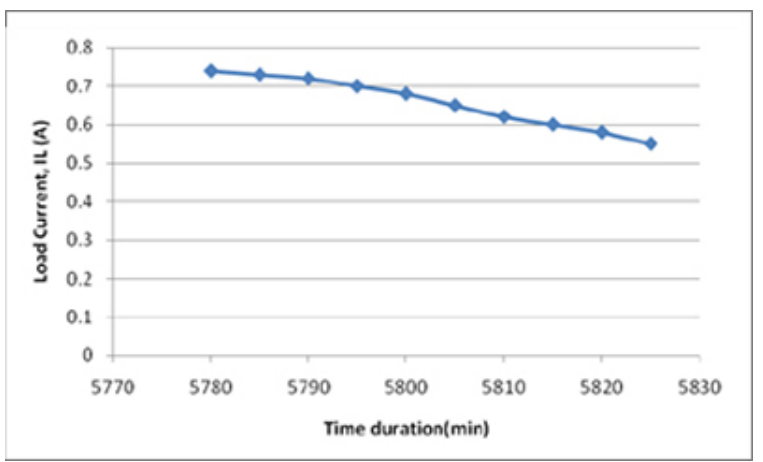

Figure 14: Variation of load current with the variation of time duration

Figure 14 shows the variation of load current with the variation of time duration for 5825 minutes on $5^{\text {th }}$ day without load. It is shown that the load current variation from $0.74 \mathrm{~A}$ to $0.55 \mathrm{~A}$. The change of short circuit current was $0.19 \mathrm{~A}$

Date: (04.11.09-08.11.09)

Table 7: Variation of maximum voltage PKL module with the variation of different dates of the month for fan.

\begin{tabular}{|c|c|}
\hline Date of the month of the year & $\begin{array}{c}\text { Maximum Voltage with load (Fan) } \\
\text { (V) }\end{array}$ \\
\hline 04.11 .09 & 4.40 \\
\hline 05.11 .09 & 4.26 \\
\hline 07.11 .09 & 4.00 \\
\hline 08.11 .09 & 3.89 \\
\hline 09.11 .09 & 3.61 \\
\hline
\end{tabular}

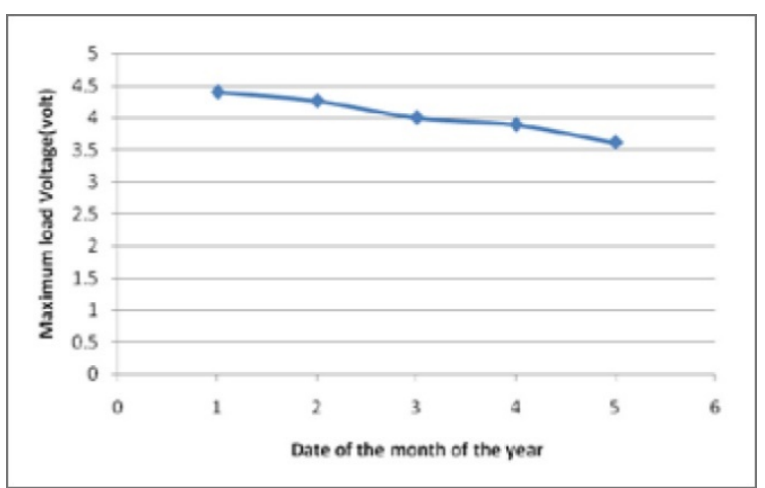

Figure 15: Variation of maximum load voltage with the variation of date of the month of the year
Figure 15 shows the variation of maximum load voltage with the variation of date of the month of the year with load voltage. It is shown that the maximum load voltage variation from $4.40 \mathrm{~V}$ to $3.61 \mathrm{~V}$. The change of short circuit current was $0.79 \mathrm{~V}$.

Date: (04.11.09-08.11.09)

\begin{tabular}{|c|c|}
\hline \multicolumn{2}{|c|}{$\begin{array}{c}\text { Table 8: Variation of minimum voltage PKL module with the variation } \\
\text { of different dates of the month for Fan }\end{array}$} \\
\hline Date & Minimum voltage with Load (Volt) \\
\hline 04.11 .09 & 3.65 \\
\hline 05.10 .09 & 3.55 \\
\hline 07.11 .09 & 3.50 \\
\hline 08.11 .09 & 3.40 \\
\hline 09.11 .09 & 3.35 \\
\hline
\end{tabular}

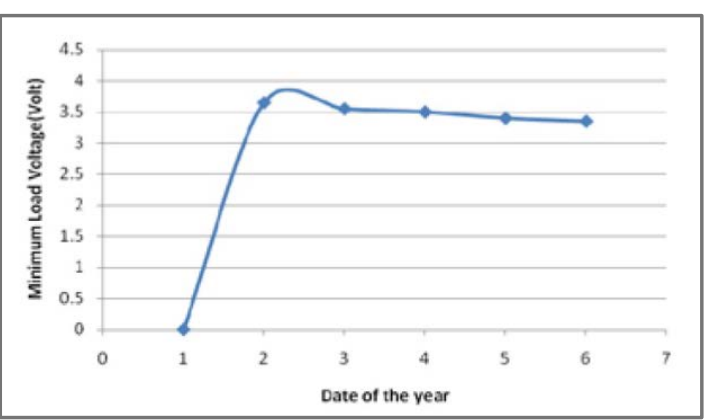

Figure 16: Variation of minimum load voltage with the variation of date of the year

Figure 16 shows the variation of minimum load voltage with the variation of date of the month of the year with load voltage. It is shown that the minimum load voltage variation from $3.65 \mathrm{~V}$ to $3.35 \mathrm{~V}$. The change of short circuit current was $0.30 \mathrm{~V}$.

\section{CONCLUSION}

The further study is necessary for the improvement of the performance of PKL electricity generation, storage \& practical utilization. In this respect for some suggestions, observations and recommendations are given below:

${ }^{*}$ The variation of load current is greater than the variation of short circuit current.

*The variation of load voltage is also greater than the variation of open circuit voltage current.

*In this research work PKL electricity has been prepared in an ordinary laboratory conditions. The laboratory facilities should be improved so that the growth parameters can be well controlled.

*The different methods preparation of PKL electricity can be exercised for comparative study of the performance of PKL electricity.

*The preparation of PKL electricity could be under taken as this electricity is commonly used every where of Bangladesh.

*The efforts to characteristics the prepared electricity by different methods may be continued. The result from this test can give more important information on the PKL electricity generation.

* It has to be established a PKL power plant some instruments can be designed and fabricated such as inverter, charge controller, storage battery etc.

*It has to be selected the unused land for cultivation of PKL in an nonagricultural land.

*The variation of maximum load voltage is greater than the variation of minimum load voltage.

\section{REFERENCES}

Amelar R.D., Dublin L., Schoenfeld C., 1973. Semen analysis: An office technique. Urology, 2, Pp. 606-11. 
Aprioku J.S., Obianime A.W., 2014. Evaluation of the effects of Citrus aurantifolia (Lime) juice in lead-induced haematological and testicular toxicities in rats. Pharmacologia, 5, Pp. 36-41.

Asiedu-Gyekye I.J., Antwi D.A., Bugyei K.A., Awortwe C., 2012. Comparative study of two kalanchoe species: total flavonoid, phenolic contents and antioxidant properties. Afr. J. Pure Appl. Chem., 6, Pp. 65-73.

Biswas S.K., Chowdhury A., Das J., Hosen S.M.Z., Uddin R., Rahaman M.S., 2011. Literature review on pharmacological potentials of Kalanchoe pinnata (Crassulaceae). Afr. J. Pharm. Pharmacol., 5, Pp. 1258-62.

Cao H., Xia J., Xu D., Lu B., Chen G., 2005. The separation and identification of the flavonoids from the leaves of Bryophyllum pinnatum. Zhong Yao Cai, 28, Pp. 988-90.

Guyton, A.C., 2006. Textbook of Medical Physiology. 11th ed. Philadelphia: Elsevier Saunders.

Hamid M.R., 2013. Characterization of a Battery cell fueled by Bryophyllum Pinnatum sap, International Journal of Scientific \& Engineering Research, 4 (3), Pp. 2229-5518.

Hamid M.R., Yusuf A., Wadud A.M.A., and Rahaman M.M., 2016. Design and Performance Test of a Prototype of a 12 Volt DC Battery Fueled by Bryophyllum Pinnatum Sap and Improvement of Its Characteristics, Department of Electrical and Electronic Engineering, Ahsanullah University of Science and Technology, Dhaka, Bangladesh, Email: \{drhamidbd, shohan933\}@gmail.com, \{akib147, sshaon95\}@yahoo.com, International Journal of Electronics and Electrical Engineering, 4 (5).

https://www.ccac.ca/Documents/Standards/Guidelines/Farm_ Animals.pdf.

Jagessar R.C., Allen R., 2012. Phytochemical screening and atomic absorption spectroscopic studies of solvent type extract from leaves of Terminalia catappa, (Almond). Acad. Res. In., 3, Pp. 17-26.

Larrey D.A., Chan J.E., Ngogang J.Y., Cai X., Vinson J.A., 1994. Antioxidant Capacity of some Herbs/Spices: A Comparative Study of two Methods. J. Agric. Food Chem., 53, Pp. 6819-24.

Marriage, P.B., Wils1on, B.G., 1971. Analysis of the organic acids of Bryophylum pinnatum. Can. J. Biochem., 11, Pp. 1500-2.

Michael B., Yano B., Sellers R.S., Perry R., Morton D., Roome N., 2007.Evaluation of organ weights for rodent and nonrodent toxicity studies: A review of regulatory guidelines and a survey of current practices. Toxicol. Pathol., 35, Pp. 742-50.

Obianime A.W., Aprioku J.S., Esomonu C.T.O., 2010. Antifertility effects of aqueous crude extract of Ocimum gratissimum L. leaf in male mice. J. Med. Plants Res., 4, Pp. 809-16.
Ochei O., Kolhatker A., 2002. Medical Laboratory Science, Theory and Practice. 5th ed. New Delhi: Tata McGraw-Hill Publishing Company Limited.

Ojewole J.A.O., 2002. Antihypertensive properties of Bryophyllum pinnatum (Lam.) Oken leaf extracts. Am. J. Hypertens., 15, Pp. 34.

Ojewole J.A.O., 2005. Antinociceptive, anti-inflammatory and antidiabetic effects of Bryophyllum pinnatum (Crassulaceae) leaf aqueous extract. J. Ethnopharmacol, 99, Pp. 13-9.

Okwu D.E., Josiah, C., 2006. Evaluation of the chemical composition of two Nigerian medicinal plants. Afr. J. Biotech, 5, Pp. 357-61.

Osujih, M., 1993. Exploration of the frontiers of tradomedical practices: basis for development of alternative medical healthcare services in developing countries. J.R. Soc. Health, 113, Pp. 190-4.

Ozolua R.I., Idogun, S.E., Tafamel G.E. 2010. Acute and subacute toxicological assessment of aqueous leaf extract of Bryophyllum pinnatum (Lam.) in Sprague-Dawley rats. Am. J. Pharmacol. Toxicol., 5, Pp. 145-51.

Pal S., Chaudhuri A.K.N., 1991. Studies on the anti-ulcer activity of a Bryophyllum pinnatum leaf extract in experimental animals. J. Ethanopharmacol., 33, Pp. 97-102.

Saad B., Abdelmoneim I., Adam G., and Elghazali L., 2006. Traditional Arab herbal medicine, evidence-based complementary and alternative medicine. J. Ethnopharmacol., 90, Pp. 625-7.

Supratman U., Fujita T., Akiyama K., and Hayashi H., 2000. New insecticidal bufadienolide, bryophyllin C, from Kalanchoe pinnata. Biosci Biotechnol Biochem, 64, Pp. 1310-12.

Tietz N.W., Pruden E.L., Siggard-Anderson O., 1986. Electrolytes, blood gasses and acid base balance in textbook of clinical chemistry. Philadelphia: Saunders.

Weatherbum M.W., 1967. Phenyl-hypochlorite reaction for determination of ammonia. Anal Chem, 39, Pp. 971-4.

Yamagishi T., Haruna M., Yan X.Z., Chang J.J., Lee K.H., 1989. Antitumor agents, 110, Bryophyllin B, a novel potent cytotoxic bufadienoiide from Bryophyllum pinnatum. J. Nat. Prod., 52, Pp. 1071-9.

Zhang W., Fievez L., Cheu E., Bureau F., Rong W., Zhang Y., 2010 Antiinflammatory effects of formoterol and ipratropium bromide against acute cadmium-induced pulmonary inflammation in rats. Eur. J. Pharmacol., 628, Pp. 171-8.

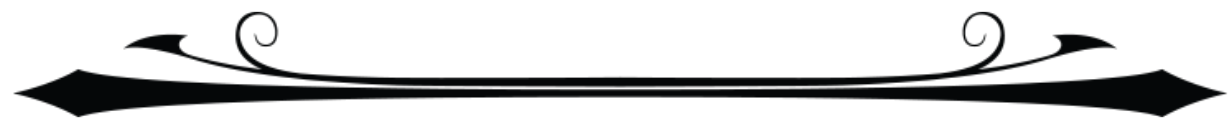

